\title{
Modelling of wave climate and sediment transport patterns at a tideless embayed beach, Pirita Beach, Estonia
}

\author{
Tarmo Soomere $^{\mathrm{a}}$ (corresponding author), Andres Kask ${ }^{\mathrm{b}}$ Jüri Kask $^{\mathrm{c}}$, Terry Healy ${ }^{\mathrm{d}}$ \\ ${ }^{a}$ Institute of Cybernetics at Tallinn University of Technology, Akadeemia tee 21, 12618 \\ Tallinn, Estonia; soomere@ cs.ioc.ee, tel. +3726204176, +3725028921, fax +3726204151 \\ ${ }^{\mathrm{b}}$ Department of Civil Engineering, Tallinn University of Technology \\ ${ }^{\mathrm{c}}$ Marine Systems Institute at Tallinn University of Technology \\ ${ }^{\mathrm{d}}$ Coastal Marine Group, Earth and Ocean Sciences, University of Waikato, New Zealand \\ submitted to Journal of Marine Systems, \\ Special Issue: Proceedings of the Baltic Sea Science Congress \\ Revised version 09.03.2008
}

\begin{abstract}
Nearshore sand transport patterns along the tideless, embayed Pirita beach, Tallinn, Estonia, have been investigated utilizing high-resolution modelling of wave processes combined with bathymetric surveys and sediment textural analyses of the nearshore sea floor. Textural analysis showed the mean grain size is about $0.12 \mathrm{~mm}$. Fine sand $(0.063-$ $0.125 \mathrm{~mm})$ accounts for about $77 \%$ of the sediments. Coarser-grained sand $(0.28 \mathrm{~mm})$ dominates along the waterline. Based upon the spatial distribution of the mean grain size and basic features of the local wave activity, properties of the Dean Equilibrium Beach Profile were determined.

Alongshore sediment transport was calculated based upon a long-term time series of wave properties along the beach, and the CERC formula applied to about $500 \mathrm{~m}$ long beach sectors. The time series of wave fields and the properties of the local wave climate were modelled using a triple nested WAM wave model with an extended spectral range for short waves. The model is forced by open sea wind data from Kalbådagrund for the years 1981-2002. Results indicate that typical closure depth at Pirita is $2.5 \mathrm{~m}$. The width and mean slope of the equilibrium profile are $250 \mathrm{~m}$ and 1:100, respectively. Southward transport dominates in the northern sections of the beach whereas no prevailing transport direction exists in the southern sections. This pattern has several nontrivial implications for the planning of beach protection activities.
\end{abstract}


Key words: sediment transport, sediment distribution, beaches, wave climate, wave modelling, Tallinn Bay

\section{Introduction}

Pirita Beach, a typical small, embayed beach of the southern coast of the Gulf of Finland, is located at the south-eastern bayhead of Tallinn Bay, Estonia (Fig. 1). This young coast obtained its contemporary shape only a few millennia ago and is in active development. The area experiences relatively rapid postglacial uplift, about 1.8-2.5 mm/year according to estimates of Zhelnin (1966), Miidel and Jantunen (1992), and Vallner et al. (1998).
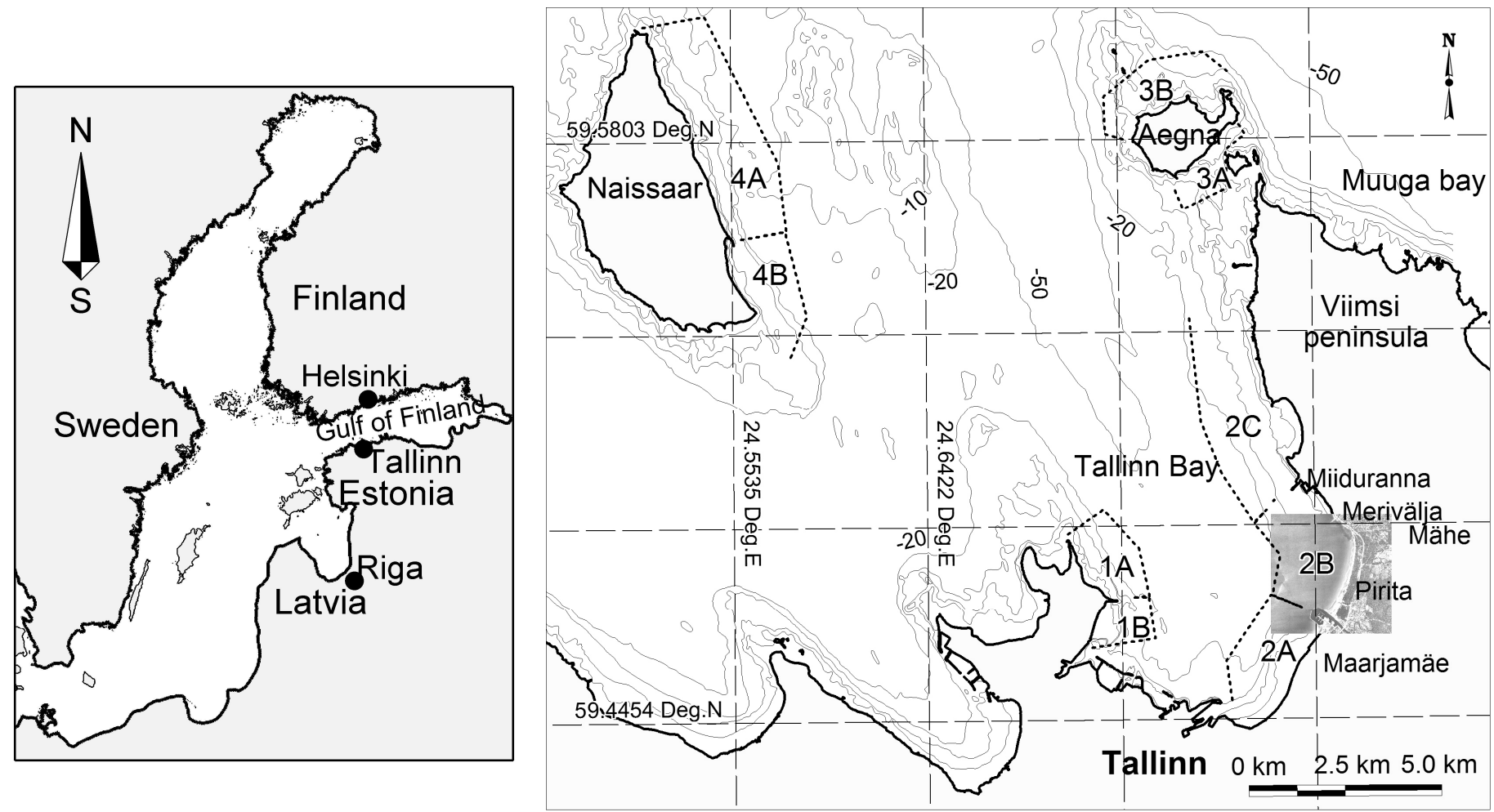

Figure 1. Location scheme of the Baltic Sea and the Gulf of Finland (left panel) and location of Pirita Beach in Tallinn Bay (right panel), showing identified cells of sediment transport after Soomere et al. (2007) and isobaths of $-2,-5,-10,-20$, and $-50 \mathrm{~m}$.

The sandy area of Pirita Beach is limited to a $\sim 2 \mathrm{~km}$ long section extending from the northern mole of the Pirita River mouth to a till cliff located about $400 \mathrm{~m}$ southwards from Merivälja Jetty (Fig. 2). The width of the dry beach is a few tens of meters, 
extending to 10 s of meters where trapped by the mole at the southern end of the beach. The dunes are relatively low with a maximum height of the cut dune scarp of $\sim 1.5 \mathrm{~m}$.

As the entire northern coast of Estonia generally suffers from sediment deficit (Orviku, 1974, Orviku and Granö 1992), it is not surprising that a certain net loss of sand at times occurs in the Pirita area. Prior to the mid $20^{\text {th }}$ century the beach was apparently stabilized by the postglacial uplift and natural sediment supplies. During recent decades, however, a gradual decrease of the dry beach width, rapid recession of the till cliff at the northern end of the beach, and extensive storm damage to the dunes, have occurred despite the postglacial uplift and attempts to renourish the beach with material dredged from Pirita Harbour or transported from mainland quarries (Soomere et al. 2007).

Alterations of natural conditions such as large-scale changes in storminess in the 1960s (Alexandersson et al. 1998), may have caused increasing loads on Baltic beaches (Orviku et al. 2003). Yet a more probable reason for large scale recent changes at Pirita Beach relates directly or indirectly to a number of major coastal engineering structures (Soomere et al. 2007). For example, construction of Miiduranna Port has essentially blocked all littoral transport from the North since the 1970s, while construction of Pirita Harbour substantially decreased the river supply of sand.

Pirita, therefore, is a typical example of a beach whose evolution has been largely controlled by development works. An important issue for its sustainable management is establishing the parameters of its equilibrium regime, the magnitude of the sediment supplies, and the basic mechanism of the natural sediment transport processes. Based on this information, well-justified decisions can be made for its protection or reconstruction. Since the sediment transport processes are already substantially modified by various development works, numerical modelling is applied to simulate the natural situation.

The central goal of this paper is to quantify the variability of the local wave regime and wave-induced sediment transport processes along the beach. It is achieved by combining efforts in high-resolution wave modelling and surveys of bottom sediments in the surf zone with the CERC sediment transport model. The parameters of the equilibrium beach profile are established as a by-product of the joint study of wave climate and spatial distribution of different grain size fractions of bottom sediments. This 
knowledge is crucial for complementary studies of net sand budget at Pirita based upon the shoreline changes during the last decades of the 20th century.

An introduction to the study area, its geological features, and general description of its functioning is presented in Section 2. The basic features of the wave modelling technology are described in Section 3. The potential transport rates along the beach are calculated in Section 4. Finally, potential consequences and applications of the modelled sand transport patterns and ways of sustainable beach protection are discussed.

\section{Sediments in the Pirita area}

\subsection{Geomorphology and forcing processes}

The shores of Tallinn Bay comprise a variety of essentially independent cells (Fig. 1). Pirita Beach forms a part of the south-western cell 2B according to Soomere et al. (2007). Together with cells $2 \mathrm{~A}$ and $2 \mathrm{C}$ it formed a unified cell until the 1920s. Today cell $2 \mathrm{C}$ is separated from the beach by Miiduranna Port. The beach southwards from the Pirita River (cell 2A in Fig. 1) was substantially modified by the construction of a seawall in the 1970s and nowadays is an artificial shore. For that reason we consider only the beach section northwards from the harbour. Cell $2 \mathrm{C}$ may be partially connected with the adjacent cell in Muuga Bay through a narrow (about $300 \mathrm{~m}$ ) and shallow (about $1 \mathrm{~m}$ before dredging) strait. Sand bodies $3 \mathrm{~A}$ and $3 \mathrm{~B}$ at the Island of Aegna are almost separated from the mainland coasts.

Technically, erosion dominates in the entire nearshore of the Viimsi Peninsula northwards from Pirita Beach out to a depth of about 10 m (Lutt and Tammik, 1992). Beach erosion, however, is not necessarily active since the shoreline is mostly covered by an armoured or lag pavement of pebbles, cobbles and boulders (Kask et al. 2003) and postglacial uplift favours the increase of the dry land area. The nearshore has a limited amount of gravel and sand as is typical for the northern coast of Estonia. Finer fractions are only released from the bluff during storm surges when waves impact directly upon unprotected sand or till.

Sediment accumulation dominates in the deeper part of Tallinn Bay and in the vicinity of Pirita Beach (Lutt and Tammik 1992). This process has a modest intensity: the 
thickness of recent dune and marine sand is modest (usually 2-2.5 m). Noticeably contemporary dunes and valleys exist only in the immediate vicinity of the coast, whereas much higher ancient dunes exist about 1-2 km inland. Dimensions of the marine sand layer diminish towards Merivälja and Maarjamäe, where a layer of till becomes evident either on the surface or below a thin layer of contemporary deposits.

Beach profiles measured out to about $1 \mathrm{~m}$ depth as well as bathymetric surveys perfomed in April 2006 down to $10 \mathrm{~m}$ depth (Fig. 2) illustrate a very gently sloping nearshore (evidently reflecting the equilibrium beach profile) at about 1:100 in the northern part of the beach and about 1:150 in the central section down to depths of about 2-2.5 m. The gentlest slope (about 1:200) is found in the southern section. Shallow-water sand bars of relative height $\sim 0.5 \mathrm{~m}$ are more frequent in the central part of the bay (Soomere et al. 2007).

Offshore from the beach, the sea floor drops relatively rapidly between the 2-4 $\mathrm{m}$ isobaths, but forms a gently sloping area about 500 to $800 \mathrm{~m}$ wide and with a slope of about 1:200 at depths of 4-7 m. The water depth increases relatively rapidly from 7 to over $10 \mathrm{~m}$ at a distance of about $700 \mathrm{~m}$ from the coast in the southern part of the beach. The width of the area with a depth of $<7 \mathrm{~m}$ deep extends to $\sim 1200 \mathrm{~m}$ in the central part of the beach. A prominent elongated elevation (probably a large sand bar) of moderate height (about $30 \mathrm{~cm}$ ) extends through a large part of the deeper $(>4 \mathrm{~m})$ section of the study area obliquely with respect to the depth contours.

Sand transport and recycling in beaches is driven by a large number of various processes such as surface waves, wind-induced transport, coastal currents and waveinduced alongshore flows, variations of water level, and in high latitudes, the effects of sea ice.

Sea ice may cause extensive damage to the dune forest at Pirita but usually it does not affect the equilibrium beach profile. Its effect is mostly indirect and consists in reducing the wave loads during the ice season. Coastal currents have a modest intensity in the entire Gulf of Finland (Alenius et al. 1998). Their typical speed is $10-20 \mathrm{~cm} / \mathrm{s}$ and only in exceptional cases exceeds $30 \mathrm{~cm} / \mathrm{s}$. Such currents practically do not contribute to the sand transport but may transport finer fractions that are suspended in the water 
column by other processes (Erm and Soomere 2006). The wave-induced sand transport greatly exceeds the current-induced transport even at relatively large depths $(8-10 \mathrm{~m})$ near Tallinn Bay (Soomere et al. 2005).

The role of wind-induced sediment transport and dune recovery apparently has been larger in the past when the coastal forest was young, the sandy strip was wider, and local sandstorms occurred (Raukas and Teedumäe 1997). The contemporary narrow beach is oriented parallel to the dominating SW winds (Soomere and Keevallik 2003) and is partially sheltered by the ever increasing number of high buildings of the City of Tallinn. Strong onshore (NW) winds typically occur either during the late stage of storms or during the autumn months when sand is wet. As a result, the intensity of dune building is modest and the height of the existing dunes is a few meters.

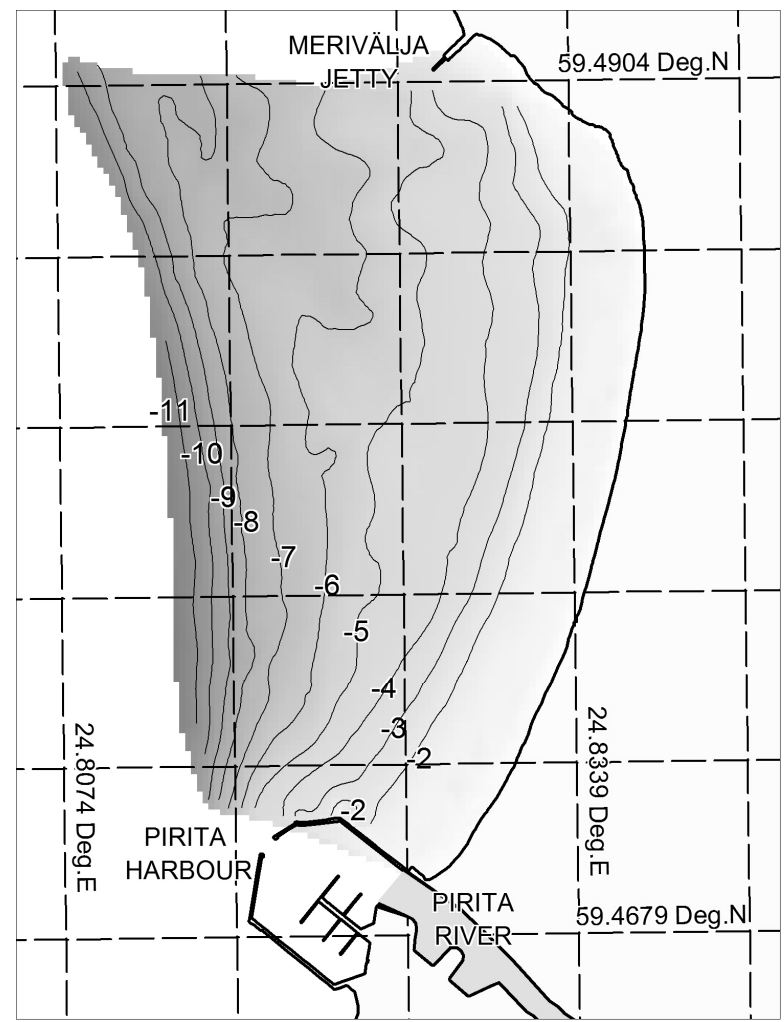

Figure 2. Bathymetry offshore from Pirita Beach based upon the 2006 hydrographic survey (Soomere et al. 2007). 
Tallinn Bay is practically tideless (Alenius et al. 1998). The synoptic water level is mainly controlled by hydrometeorological factors. Typical deviations of the water level from the long-term average are a few tens of centimetres even in very strong storms. Water levels exceeding the long-term mean by more than $1 \mathrm{~m}$ are rare. The highest measured level is $152 \mathrm{~cm}$ and the lowest level is $-95 \mathrm{~cm}$ (Suursaar et al. 2006). Given the essentially tideless conditions, surface waves play a particularly dominant role in the functioning of Pirita Beach. Since the variations of the water level are small compared to the area covered by sand at Pirita, waves always act upon the sandy part of the beach.

\subsection{Sediment supplies and transport patterns}

The natural supplies of sand to the beach are the Pirita River, littoral transport along the western coast of the Viimsi Peninsula, and sporadic erosion of sand from a glacial till scarp near Merivälja Jetty at the northern end of the sandy sector as well as from the dunes of the middle and the northern part of the beach (Soomere et al. 2007).

Dominant waves approach the Viimsi Peninsula from the West or NW (Soomere 2005) and thus cause southwards littoral transport. Establishing its potential rate and variability is one of the goals of this study. A well-defined multiple bar system is illustrated along the beach in Fig. 3. Its geometry of a single bar in the north splitting to multiple bars in the south is consistent with the southwards net littoral drift and greater available sediment in the beach system trapped by the mole. This direction becomes visible also from an elongated accumulation feature north-westwards from Miiduranna Port. This is opposite to the usual eastwards littoral drift along straight sections of the southern coast of the Gulf of Finland (Orviku and Granö 1992, Laanearu et al. 2007) and reflects a specific feature of North Estonian semi-sheltered bays.

The littoral drift has undergone major changes during the last century. While the construction of Merivälja Jetty out to about 3 m water depth in 1925-1927 diminished the transport of coarser sediments, Miiduranna Port, a large harbour complex on an Estonian scale that was commenced in the 1970s, almost completely blocks wave-induced alongshore sediment transport. Its quays extend out to the natural depth of 6-8 $\mathrm{m}$. At the turn of the millennium the depth of its fairway was dredged to $13 \mathrm{~m}$. This blocking 
eventually lead to sediment deficit and relatively fast erosion southwards from these constructions.

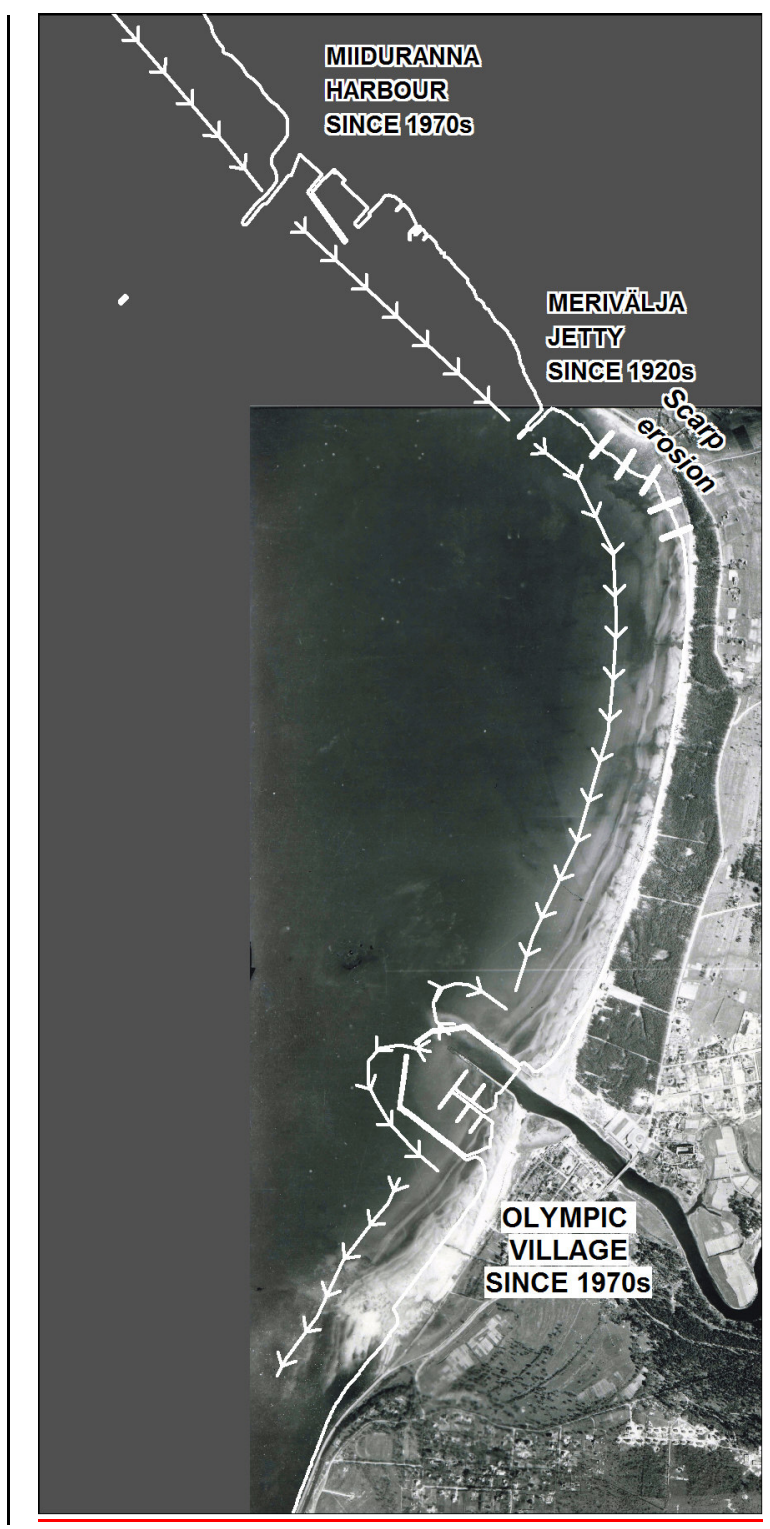

Figure 3. Sediment transport directions at Pirita Beach on the background of an aerial photo from 1951 (Soomere et al. 2007).

Pirita River delivers about $400 \mathrm{~m}^{3} /$ year of very fine (grain size $<0.05 \mathrm{~mm}$ ) matter annually to Tallinn Bay (Lutt and Kask 1992). Since 1928 two groins stretching from the Pirita River mouth out to $\sim 3 \mathrm{~m}$ water depth almost completely stopped the supply of coarser sand from the river discharge. Even if a certain amount of bedload transport of coarser-grain sand fed the beach during spring and autumn floods in the past, today it is blocked by the Olympic sailing harbour that was built in the mid-1970s and today acts as a settling basin. Only a very limited amount of fine sediments now reaches the sea. Moreover, this material is directed far offshore from the equilibrium beach profile. 
A revetment from granite stones was constructed along the dune toe in the 1980s to protect dunes in the northern sections of Pirita Beach against erosion. The till scarp at Merivälja Jetty (Fig. 3) that was subjected to direct wave action under storm surge conditions was protected by a new seawall in 2006-2007.

Dumped, at least partly sandy, dredged material has also increased the active sand mass of the beach in the past. From the late 1950s, sediments from the river mouth were pumped to the northern side of the mole, but no reliable data are available about the sediment size and volume of the dredged material (Soomere et al. 2007). About 65000 $\mathrm{m}^{3}$ of dredged sand was dumped near Merivälja Jetty in the 1970s on the expectation that waves would transport the sand southwards to Pirita Beach. Since sand in more than $1 \mathrm{~m}$ deep water is not necessarily transported alongshore under local conditions (Soomere et al. 2005), it is unclear how much of that sand actually reached the beach.

To summarize, the coastal engineering activities of the past century have essentially blocked the major supplies of sand to Pirita Beach. The potential misbalance of the supply of different fractions is expected to become evident as a gradual decrease of the beach dominant grain size, resulting in an overall worsening of the sand quality from a recreational viewpoint. On the other hand, Pirita Harbour blocks the lateral sand loss from the beach. The beach profile, therefore, should be relatively stable and the concept of the equilibrium beach profile is accordingly an appropriate tool for its analysis.

\subsection{Contemporary marine sand}

Earlier studies of sediments on the sea floor near Pirita are based upon 33 short drill cores extending to a depth of $2.1 \mathrm{~m}$ into the sea floor (Lutt 1992). The seabed from the waterline down to depths of $2-3 \mathrm{~m}$ is covered with fine sand, grading to coarse $\operatorname{silt}^{1}$ at depths of 6-8 m. In deeper areas finer silt fractions dominate (Lutt 1992). The total thickness of the sand mass is usually over $2 \mathrm{~m}$ but apparently does not exceed 10-15 $\mathrm{m}$. In deeper areas, the sampled layer entirely consists of relatively well-sorted silt. Several thin medium- and coarse-grained sand bodies were detected at the depths from about $2 \mathrm{~m}$

\footnotetext{
${ }^{1}$ We follow the classification of (Friedman et al. 1992) where the fractions with the grain size $<0.063$ are termed silt. Fractions with the grain size from 0.063 to $0.2 \mathrm{~mm}$ are together referred to as fine sand, fractions from 0.2 to $0.63 \mathrm{~mm}$ as medium sand, fractions from 0.63 to $2 \mathrm{~mm}$ as coarse sand, and fractions with the grain size $>2.0 \mathrm{~mm}$ as gravel.
} 
up to $10 \mathrm{~m}$. Such stratigraphy may reflect the attempts of beach fill or changes of sediment recycling due to coastal engineering structures. It, however, may also have a natural background, because similar depositional sequences can be followed in some sandy areas adjacent to several other North Estonian river mouths (Lutt 1992).

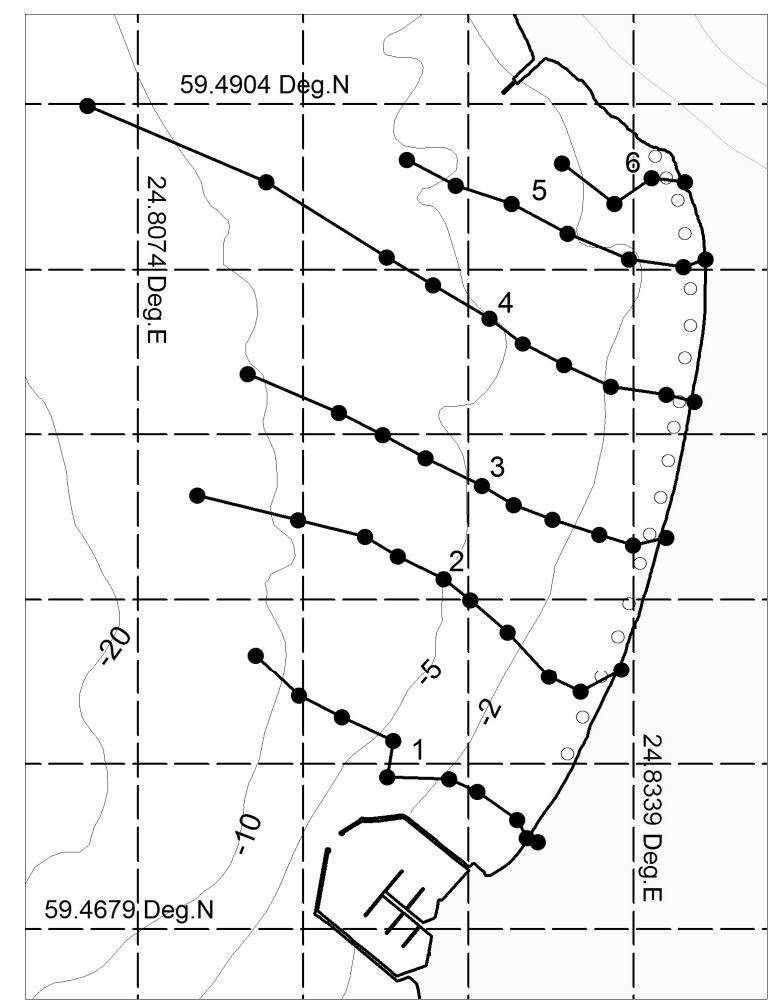

Figure 4. Sampling points of bottom sediments at Pirita in 2005 (profiles 1-6, filled circles) and 2007 (points in the nearshore, empty circles, Soomere et al. 2007). Isobaths are shown based on the digital 1:50000 map from the Estonian Land Board (www.maaamet.ee).

The transition between the fine and coarse sand bodies is quite sharp whereas the transition between fine sand and different silt fractions is generally gradational. Coarser sand bodies are poorly sorted at Pirita and contain a number of different fractions, none of which dominates, whereas the fine sand bodies usually have a narrow range of grain size (Lutt 1992). This property is also frequent for the North Estonian sandy areas (Lutt 1985, Lutt and Tammik 1992, Kask et al. 2003).

Sediment textural analysis of the composition of the upper layer of contemporary bottom sediments at Pirita was performed on 69 samples from the upper $30 \mathrm{~cm}$ layer of bottom sediments from the waterline to the $10 \mathrm{~m}$ isobath (Fig. 4). The mean $\phi$-values 
$M_{\phi}\left(d_{50}\right.$ in physical units) and the standard deviation $\sigma_{\phi}$ of the grain size for each sample are found from the quantiles of $\phi_{84}$ and $\phi_{16}$ as (Dean and Dalrymple 2002, Chapter 2)

$M_{\phi}=\frac{\phi_{84}+\phi_{16}}{2}, \quad \sigma_{\phi}=\frac{\phi_{84}-\phi_{16}}{2}$,

assuming the log-normal distribution of the grain size. Their approximate values (Table 1) are found from the cumulative distributions of the grain size (Soomere et al. 2007) with the use of linear approximation.

Table 1. Averaged textural properties of sand at Pirita Beach (Soomere et al. 2007).

\begin{tabular}{|l|l|l|l|l|l|}
\hline \multicolumn{1}{|c|}{ Property } & $\phi_{16}$ & $\phi_{84}$ & $M_{d}$ & $d_{50}, \mathrm{~mm}$ & $\sigma_{\phi}$ \\
\hline Vicinity of the waterline & $1.1 \phi$ & $2.53 \phi$ & $1.815 \phi$ & 0.284 & 0.715 \\
\hline Entire beach & $2.16 \phi$ & $3.84 \phi$ & $3.0 \phi$ & 0.125 & 0.84 \\
\hline Nearshore (depth <1 m, 2007) & $2.5 \phi$ & $3.68 \phi$ & $3.1 \phi$ & 0.117 & 0.59 \\
\hline
\end{tabular}

The sand is better sorted in the shallow nearshore where $\sigma_{\phi} \approx 0.6$ but poorly sorted in the rest of the beach sediment. The average grain size for the entire beach is approximately $0.12 \mathrm{~mm}$. An approximate value of the scale factor of the relevant equilibrium beach profile is thus $A=0.07$ (Dean and Dalrymple 2002, Chapter 7). This value will be used in calculations described in Section 3.2.

\subsection{Spatial distribution of bottom sediments}

The predominant sediment constituents are fine (84\%) and medium sand (13\%). Fine sand dominates in most of the beach in accordance with the earlier data (Lutt 1992, Lutt and Tammik 1992). Generally the content of medium sand is larger in the northern sections of the beach; still a local maximum of its content exists in the central part of the study area. There is very little gravel $(0.8 \%)$ and coarse sand $(3.9 \%)$ in the study area; they are mostly found in the northern part of the beach. Silt forms about $5.5 \%$; its largest content is in the deeper area (Fig. 5).

The coarsest material is usually concentrated in the vicinity of the breaker line and at the waterline of sandy beaches (Dean and Dalrymple 2002). This is only partially true for Pirita (Fig. 5) where a local maximum of the content of coarse sand is found only in 
the vicinity of the waterline. A probable reason for this feature is the intermittent nature of wave activity at Pirita (see below): the breaker line is poorly defined and the strip of relatively coarse sand does not become evident.
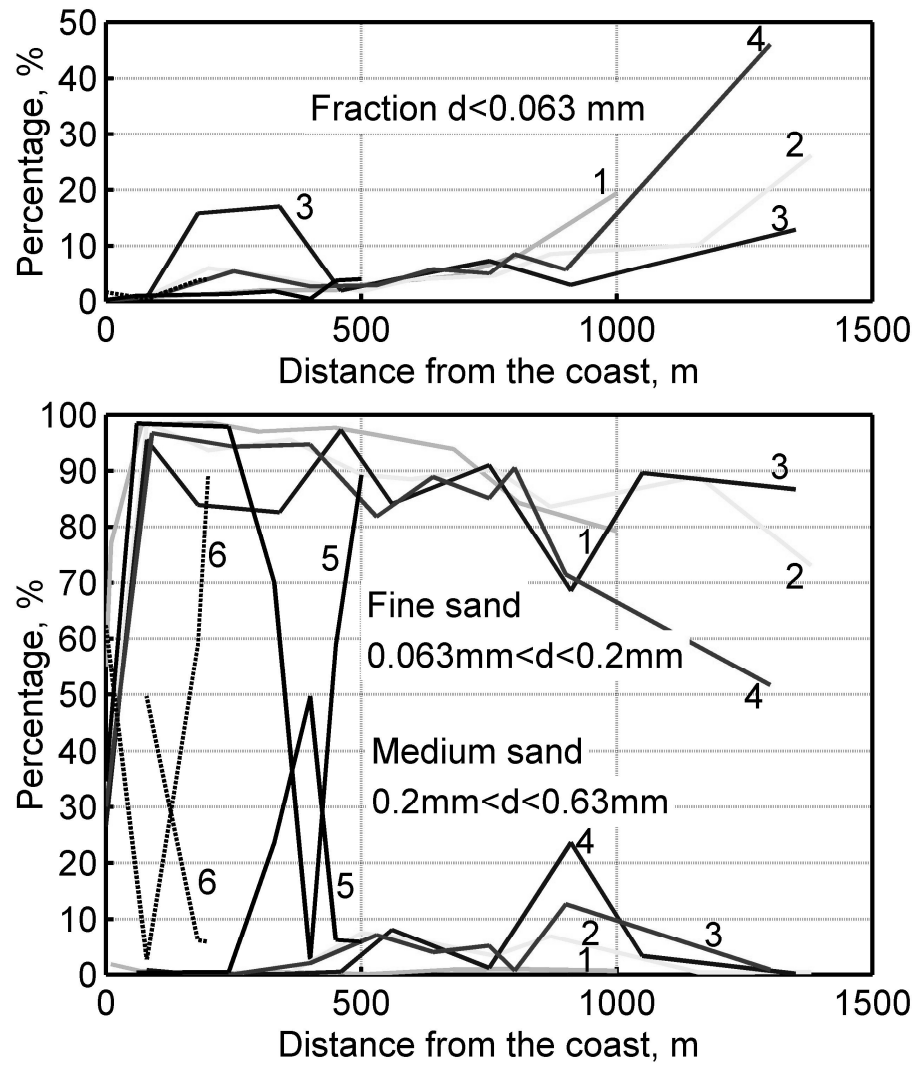

Figure 5. Properties of different grain size fractions along beach profiles 1-6 in Fig. 4 (Soomere et al. 2007).

The pattern of the alongshore variation of the content of the major fractions (Fig. 6) suggests that the entire beach is not in perfect equilibrium. Sediments are more heterogeneous and the content of coarser material is greater in the northern sections of the beach. Somewhat surprisingly, the content of silt increases northwards at greater depths. This may reflect the selective blocking of the natural sand supply by the coastal engineering structures.

Figures 5 and 6 reveal certain inhomogeneous features of the distribution of the fractions. Apart from hydrodynamic factors, the beach refill and dumping of the material 
dredged from the river mouth and Harbour basins in the 1970s may have played a role in forming of such inhomogeneities.
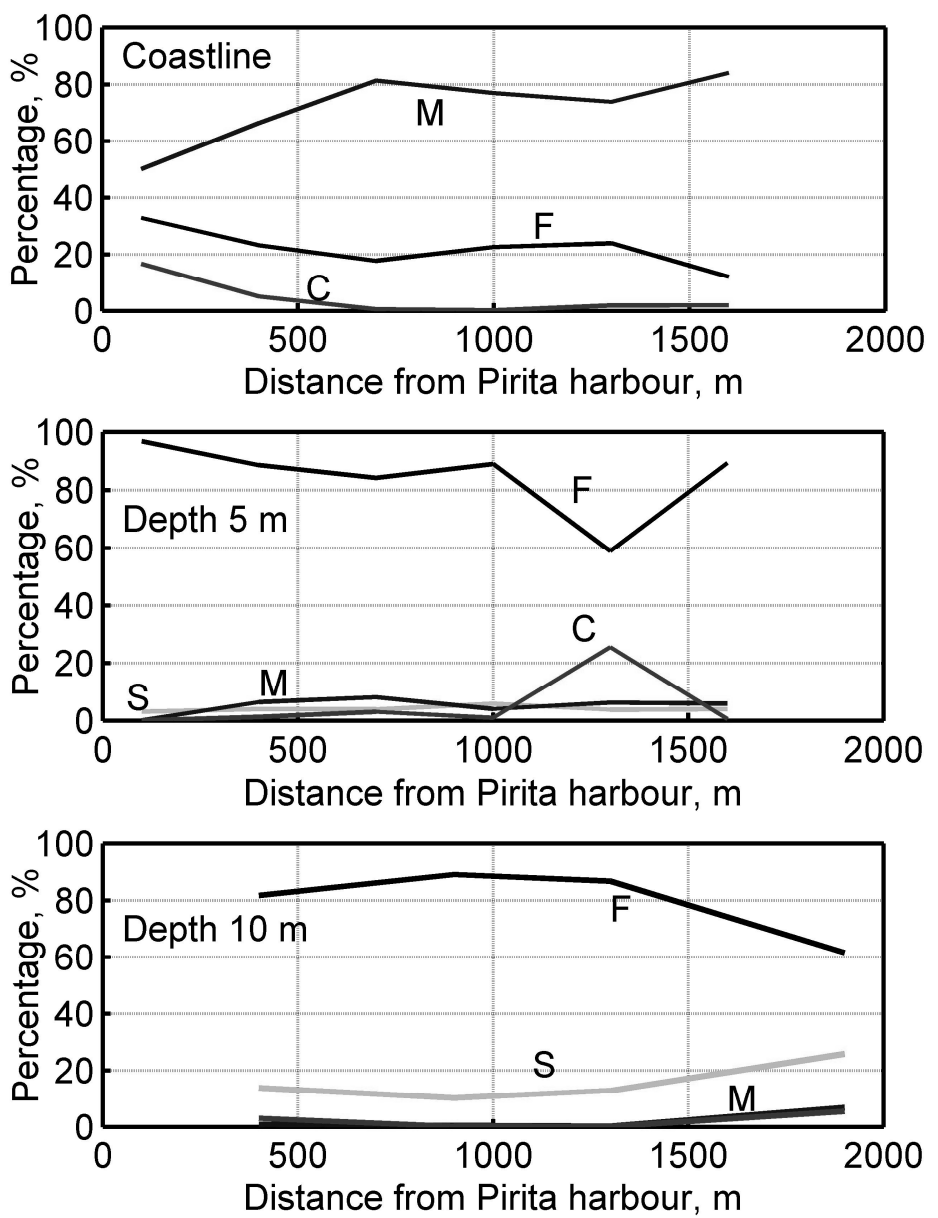

Figure 6. Properties of different grain size fractions interpolated from sediment samples along the coastline and along the $5 \mathrm{~m}$ and $10 \mathrm{~m}$ isobaths. The letter $\mathrm{C}$ stands for coarse sand, $\mathrm{M}$ for medium sand, $\mathrm{F}$ for fine sand and $\mathrm{S}$ for the fraction with the grain size $<0.063 \mathrm{~mm}$ (Soomere et al. 2007).

\section{Wave modelling}

\subsection{Features of the wave climate of Tallinn Bay}

Modelling and quantification of sediment transport is an important challenge in contemporary coastal science. A number of uncertainties are connected with inadequate knowledge of the properties of (spatial distribution of) bottom sediments and bathymetry (e.g. Kuhrts et al. 2004). Also, the properties of forcing factors are usually known only 
approximately. In many applications, establishing the order of magnitude or direction of sediment transport is considered as a satisfactory result (Davies and Villaret 2002).

The uncertainties are particularly large in simulations of past events. For Pirita, the resolution of historical wind data is $\sim 22.5^{\circ}$ for the wind direction and $1 \mathrm{~m} / \mathrm{s}$ for the wind speed. The observations exist only once in 3 or even 6 hours. The directional resolution of the wave model in use $\left(15^{\circ}\right)$ therefore allows reproduction of the wave properties with an acceptable accuracy, and the largest source of uncertainty is the wind data. The above sampling and survey of bathymetry have an effective spatial resolution of about $200 \mathrm{~m}$. This resolution allows an adequate representation of wave fields and transport properties for sections with a typical size twice exceeding this value; thus using the spatial resolution $470 \mathrm{~m}$ of the wave model matches the resolution of the bathymetry.

The above has shown that the properties of bottom sediments are more or less homogeneous over the study area. This allows use of an average value for the grain size for entire beach. Large storms may bring into motion $200-300 \mathrm{~kg} / \mathrm{m}^{2}$ of bottom sediments in the Baltic Sea (Jönsson 2005, IV-14), that is, several tens of cm thick upper layer. The samplings in 2005-2007 as well as historical data (Soomere et al. 2007) confirm that the upper $30 \mathrm{~cm}$ thick layer of sediments is mostly homogeneous. Therefore it is acceptable to assume that the active sand layer in the nearshore of the sandy strip of Pirita Beach is homogeneous, except possibly for the northernmost sector of the beach. This assumption is unacceptable northwards from the sandy beach where the sea bottom of the surf zone is mostly covered by armoured gravel pavement, where minimal sediment transport occurs.

Waves affecting Tallinn Bay and Pirita beach are primarily generated in distant sea areas of the Gulf of Finland. Westerly winds may bring to this area wave components excited in the northern sector of the Baltic proper. The wind regime in the Gulf of Finland as well as in the entire Baltic Sea is strongly anisotropic (Mietus 1998, Soomere and Keevallik 2003). The most probable wind and storm direction is SW. NNW winds are less frequent but, statistically, the strongest in the northern Baltic proper. During certain seasons, strong easterly winds may blow along the axis of the gulf (Soomere and Keevallik 2003). 
Tallinn Bay is well sheltered from high waves coming from many potential directions of strong winds. Its wave climate is relatively mild compared with the open part of the Gulf of Finland and with the sea areas adjacent to Tallinn Bay. The average significant wave height was only $0.26 \mathrm{~m}$ offshore from Miiduranna Port in 1991-2000 (Soomere 2005). The significant wave height exceeded $0.3 \mathrm{~m}(0.6 \mathrm{~m})$ with a probability of $25 \%(2.5 \%)$. The probability of occurrence of wave heights $>1 \mathrm{~m}$ was $1 \%$, whereas in the open part of the Gulf of Finland wave heights 2-2.5 m occur with this probability.

The specific feature of Tallinn Bay is that occasionally very high waves reach this area. They directly attack Pirita during strong NNW winds that occur with an appreciable frequency. This feature explains why extreme significant wave heights even in the inner region of the bay are comparable with those in the open part of the Gulf of Finland (Soomere 2005). The significant wave height exceeds $2 \mathrm{~m}$ each year and may reach $4 \mathrm{~m}$ in NNW storms in the central part of the bay (Soomere 2005). Dominating wave periods at Pirita in western and NNW storms are close to those in the central part of the Gulf of Finland and generally modest. The typical peak periods are $4-5 \mathrm{~s}$ for wave heights below $1 \mathrm{~m}$, about $6 \mathrm{~s}$ for wave heights around $2 \mathrm{~m}$, and are 8-9 s only in very strong storms when wave heights are $3 \mathrm{~m}$ or higher (Soomere 2005a, Broman et al. 2006). Waves with periods over $10 \mathrm{~s}$ are rare and usually correspond to very low swell conditions.

\subsection{Parameters of the equilibrium profile}

Although a particular beach profile may undergo substantial changes owing to various hydrodynamic forcing, an average of the instantaneous profiles over a long period usually preserves a relatively constant shape called the equilibrium beach profile (EBP, Dean 1991). The temporal and spatial resolution of available surveys is too low for adequate estimate of properties of the EBPs at Pirita. For that reason we rely on theoretical estimates of the shape of the EBP based upon the concept of uniform wave energy dissipation per unit water volume in the surf zone (Dean and Dalrymple 2002, Chapter 7). The water depth $h(y)$ along such profiles at a distance $y$ from the waterline is $h(y)=A y^{2 / 3}$, 
where the profile scale factor $A$ depends on the grain size of the bottom sediments. Since the dominating grain size insignificantly varies along the Pirita Beach, it is adequate to use a fixed value of the factor $A$ that corresponds to the overall average grain size (Dean, Walton, and Kriebel 2001). The factor $A$ is approximately $0.07-0.08$ for the northern and about 0.063 for the southern part of the beach.

Another basic parameter of the equilibrium profile is the depth of closure $h^{*}$. It is defined by Kraus (1992) as the depth where repeated survey profiles pinch out to a common line. It represents the maximum depth at which the breaking waves adjust the surf zone profile. Several authors have suggested empirical expressions for $h^{*}$ based on measures of the wave activity. Houston (1996) argues that an acceptable approximation is $h^{*} \approx 1.5 H_{s, 0.137} \approx 6.75 H_{s}^{a}$,

where $H_{s}^{a}$ is the annual mean significant wave height and $H_{s, 0.137}$ is the threshold of the significant wave height that occurs 12 hours a year, that is, the wave height that is exceeded with a probability of $0.137 \%$.

A specific feature of wave climate in the Baltic Sea is that the average wave conditions are mild, but very rough seas may occur episodically in long-lasting, strong storms (Soomere 2005, Broman et al. 2006, Soomere and Zaitseva 2007). Waves in such storms are much higher than one would estimate from the mean wave conditions. Moreover, the strongest storms in the Gulf of Finland tend to blow from directions from which winds are not very frequent (Soomere 2005, Soomere and Keevallik 2003). As a result, the simplified estimates based on the annual mean wave parameters substantially underestimate the closure depth (see Table 3 below). The reason is that they, for example Eq. (3), assume a specific ratio of $H_{s}^{a}$ and various percentiles of the significant wave height that does not necessarily hold for semi-enclosed seas.

Birkemeier (1985) suggests the following expression for the closure depth:

$$
h^{*}=p_{1} H_{s, 0.137}-p_{2} \frac{H_{s, 0.137}}{g T_{s}^{2}},
$$


where $p_{1}=1.75, p_{2}=57.9$ and $T_{s}$ is the peak period in such wave conditions. Nicholls et al. (1996) suggest $p_{1}=2.28, p_{2}=68.5$ in Eq. (4). These expressions give more realistic results for the Pirita area (Table 3) that match the results of the bathymetric survey.

Although only two parameters are necessary to estimate the closure depth, the relevant information generally is not provided in the wave atlases (e.g. Lopatukhin et al. 2006). Although there is a large pool of wave data from Tallinn Bay and from adjacent sea areas, the existing data are not sufficient for determination of the EBP. A valuable experimental data set collected in 1974-1980 (Orlenko et al. 1984) describes wave properties only during the relatively calm spring and summer seasons. Visual wave measurements at Tallinn Harbour describe only waves in the immediate vicinity of the coast (Orlenko et al. 1984). Contemporary wave measurements in the central part of the Gulf of Finland (Kahma and Pettersson 1994, Pettersson 2001) cannot be directly extended to Tallinn Bay because of a specific combination of geometry of the bay and the wind regime in this area. Wave measurements in the bay itself have been performed remote from Pirita (Soomere and Rannat 2003). Similar problems are frequently encountered in many regions of the world and long-term numerical simulations are one way to approach them.

\subsection{Wave model}

The wave climate in the vicinity of Pirita Beach is estimated on the basis of a simplified scheme for long-term wave hindcast with the use of a triple-nested version of the WAM model. This model, although constructed for open ocean conditions and for relatively deep water (Komen et al. 1994), gives good results in the Baltic proper provided the model resolution is appropriate and the wind information is correct (Tuomi et al. 1999). Since waves are relatively short in Tallinn Bay (cf. Broman et al. 2006), the innermost model (24 evenly spaced directions, grid step of about 1/4 nautical miles; covers Tallinn Bay and its vicinity) allows description of wave properties in the coastal zone, up to depth of about $5 \mathrm{~m}$ and as close to the coast as about 200-300 $\mathrm{m}$ (Soomere 2005). 


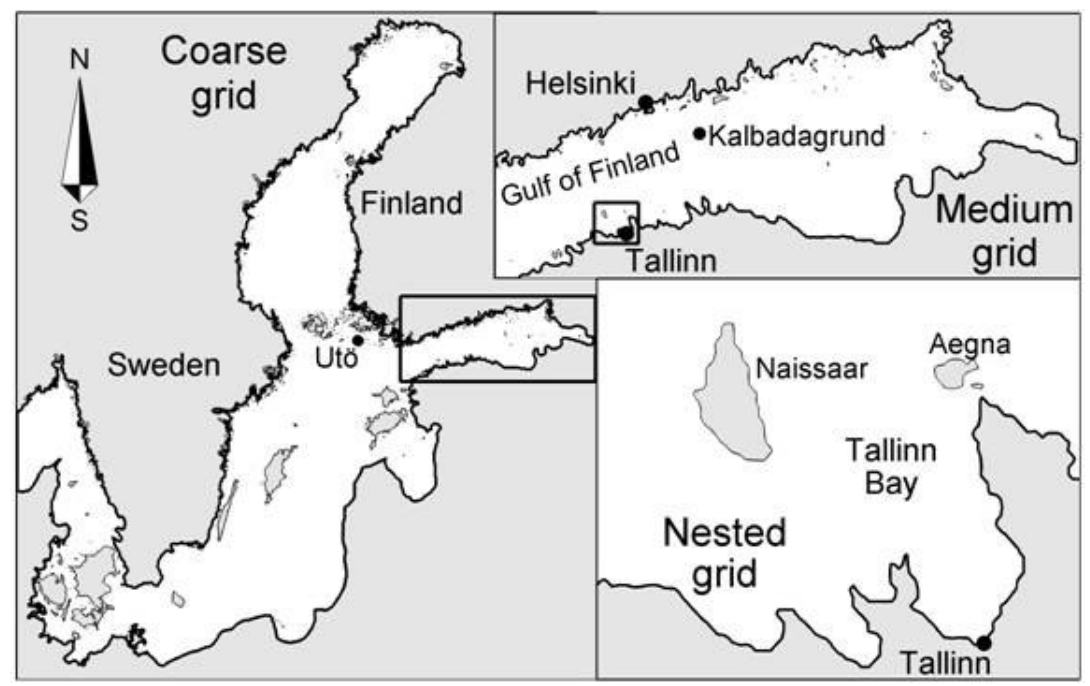

Figure 7. Computational areas of the triple-nested wave model applied to Tallinn Bay and Pirita Beach.

The basic idea of speeding up the wave computations consists in reducing longterm calculations of sea state to an analysis of a cluster of wave field maps pre-computed with the use of single-point wind data. The wave calculations are split into a number of short independent sections. To the first approximation, it is assumed that an instant wave field in Tallinn Bay is a function of a short section of wind dynamics. This is justified provided wave fields rapidly become saturated and have a relatively short memory of wind history. Moreover, it is implicitly assumed that remote wind conditions insignificantly contribute to the local wave field. These assumptions are correct in Tallinn Bay for about $99.5 \%$ cases (Soomere 2005).

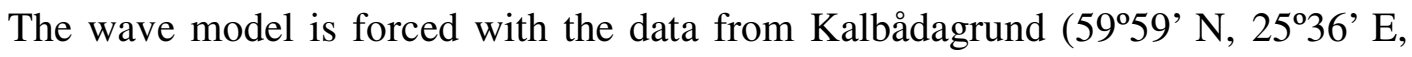
Fig. 7). This is the only measurement site in the Gulf of Finland that is practically not affected by the shores and correctly represents marine wind conditions. The presence of ice is ignored. Doing so leads to a certain bias of the results, because the mean number of ice days is from 70 to 80 annually (Climatological Ice Atlas, 1982). Statistically, the ice cover damps wind waves either partially or totally during the most windy winter season (Mietus 1998). Therefore, the computed annual mean parameters of wind waves are somewhat overestimated and represent average wave properties during the years with no extensive ice cover. 
Several improvements to the wave model were introduced compared with earlier studies (Soomere 2005). The bathymetric information for several key areas of Tallinn Bay affecting refraction of waves towards Pirita (such as southwards from Naissaar, where bathymetry was changed due to sand mining in 2005) was corrected in the innermost model from high-resolution soundings taken before sand mining in this area (Kask et al. 2005).

An appreciable portion of the wave fields at Pirita are created by weak winds in short fetch conditions. The standard frequency range (24 evenly spaced frequencies from 0.042 to $0.41 \mathrm{~Hz}$ with an increment of 1.1) of the WAM model (Komen et al. 1994) used in the earlier modelling activities (Soomere 2001, 2005) is insufficient for adequate description of such wave fields. The frequency range was extended to $2.08 \mathrm{~Hz}$ (42 evenly spaced frequencies) to better represent the wave growth in low wind and short fetch conditions. The influence of waves excited in the Baltic proper by moderate winds (6-10 $\mathrm{m} / \mathrm{s}$ ), neglected in (Soomere 2005), was taken into account here. As expected, the former model adequately reproduces the seas with relatively large wave heights $(>0.6 \mathrm{~m})$ at Pirita but underestimates the wave height for low winds from several directions and frequently fails to reproduce the low swell. The long-term average wave height at Pirita was somewhat underestimated (by 10-15\%) in earlier studies (Soomere et al. 2005).

\subsection{Modelled wave climate at Pirita}

The parameters of the nearshore wave climate were computed for five sections of Pirita beach (Fig. 8, Table 2). The size of the sectors $(470 \times 470 \mathrm{~m})$ matches the grid size of the innermost model. The simulations were performed for the years 1981-2002.

The highest waves $\left(H_{s}=2.65 \mathrm{~m}\right.$ in the northern part of the beach, $H_{s}=2.3 \mathrm{~m}$ in the southern section, peak period about $8 \mathrm{~s}$ ) apparently occurred at Pirita on 18-19 October 1998. During this night westerly winds of $22 \mathrm{~m} / \mathrm{s}$ provided favourable wave generation conditions for the Pirita area. The 6-hour mean wind speed was even larger $(23 \mathrm{~m} / \mathrm{s})$ on 15 November 2001 when the highest ever waves $H_{s}=5.2$ were measured in the Gulf of Finland (Pettersson and Boman 2002, Soomere 2005) but the fetch for winds from this direction (NNW) was much shorter. 


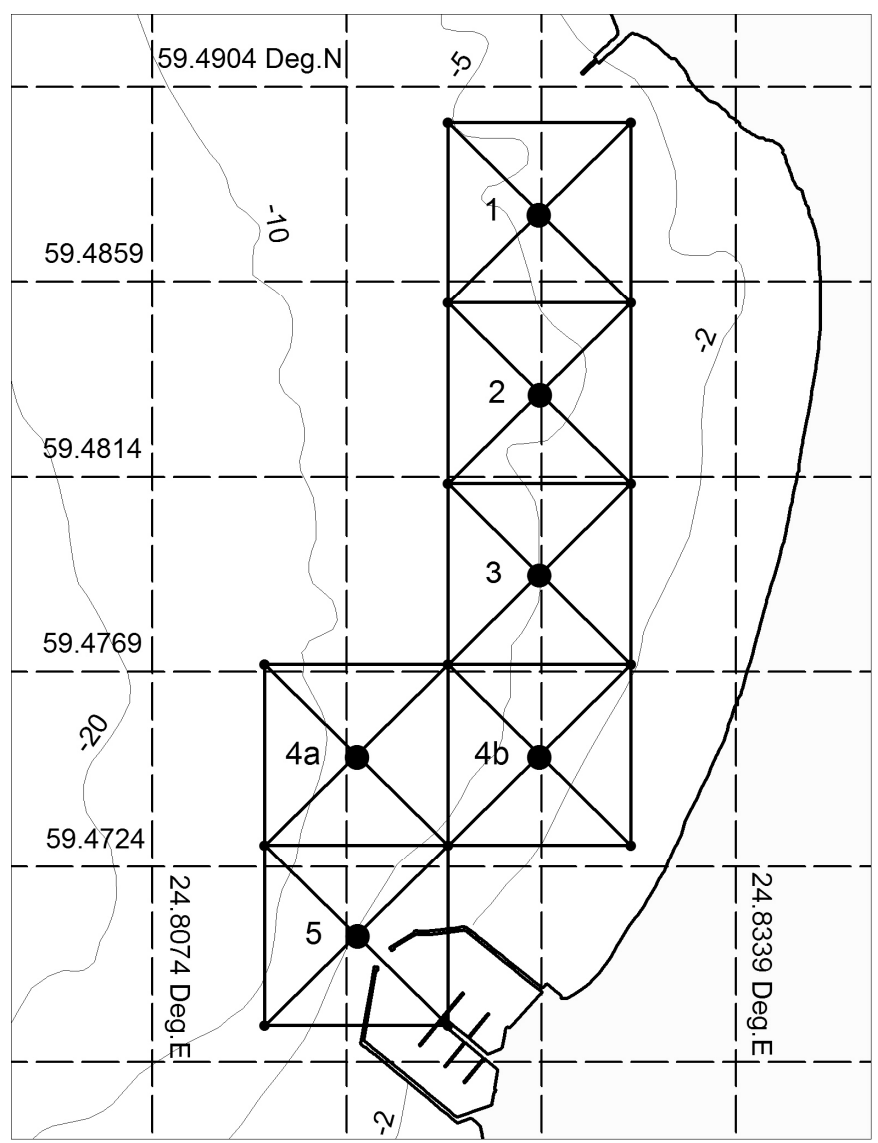

Figure 8. Sectors of Pirita Beach for which wave properties were calculated (at the centroids of the sectors). The sectors are numbered from the North to the South.

A significant wave height close to or exceeding $2 \mathrm{~m}$ occurred at Pirita about ten times during 1981-2002. Although in some of the listed cases the actual wave height apparently was smaller than the modelled values because of the ice cover, the presented statistics suggests that the return period of the significant wave height $\geq 2 \mathrm{~m}$ is about 2 years. The threshold for the significant wave height occurring with a probability of $0.137 \%$ (12 hours a year) is $1.45-1.58 \mathrm{~m}$ (Table 3$)$. The typical peak period $T_{s}$ in such storms is about $7 \mathrm{~s}$. Expression (3) suggested in Birkemeier (1985) gives reasonable values of $2.36-2.57 \mathrm{~m}$ for the closure depth that match the bathymetric survey data (Soomere, et al. 2005). With the approximate value of the scale factor $A=0.07$ (Chapter 2 ), the width of the equilibrium profile is expected to be about $250 \mathrm{~m}$ and its mean slope approximately 1:100 at Pirita. 
Table 2. Sectors of Pirita Beach.

Orientation is defined as the angle between the average direction of the isobaths at the seaward border of the surf zone within a sector and the direction to the North. Positive orientation means that isobaths stretch from SW to NE.

\begin{tabular}{|c|c|c|c|c|}
\hline $\begin{array}{l}\text { Sector } \\
\text { No. }\end{array}$ & Description & $\begin{array}{l}\text { Average } \\
\text { depth, m }\end{array}$ & $\begin{array}{l}\text { Co-ordinates } \\
\text { of the centre }\end{array}$ & $\begin{array}{c}\text { Orientation, } \\
\text { degrees }\end{array}$ \\
\hline 1 & $\begin{array}{l}\text { Northernmost sector, with a border } \\
\text { about } 200 \mathrm{~m} \text { from Merivälja jetty }\end{array}$ & 3 & $\begin{array}{l}59^{\circ} 29,25^{\prime} \mathrm{N} \\
24^{\circ} 49,5^{\prime} \mathrm{E}\end{array}$ & $-30^{\circ}$ \\
\hline 2 & Northern sector & 3 & $\begin{array}{l}59^{\circ} 29^{\prime} \mathrm{N}, \\
24^{\circ} 49,5^{\prime} \mathrm{E}\end{array}$ & $11^{\circ}$ \\
\hline 3 & Middle section of the beach & 4 & $\begin{array}{c}59^{\circ} 28,75^{\prime} \mathrm{N} \\
24^{\circ} 49,5^{\prime} \mathrm{E} \\
\end{array}$ & $17^{\circ}$ \\
\hline $4 a$ & $\begin{array}{l}\text { Deeper part of the southern section of } \\
\text { the coastal slope }\end{array}$ & 7 & $\begin{array}{l}59^{\circ} 28,5^{\prime} \mathrm{N} \\
24^{\circ} 49^{\prime} \mathrm{E}\end{array}$ & $22^{\circ}$ \\
\hline $4 b$ & $\begin{array}{l}\text { Shallower part of the southern section } \\
\text { of the coastal slope }\end{array}$ & 2 & $\begin{array}{l}59^{\circ} 28,5^{\prime} \mathrm{N} \\
24^{\circ} 49,5^{\prime} \mathrm{E}\end{array}$ & $22^{\circ}$ \\
\hline 5 & $\begin{array}{l}\text { Southernmost sector in the vicinity of } \\
\text { the northern mole of Pirita Harbour }\end{array}$ & 6 & $\begin{array}{l}59^{\circ} 28,25^{\prime} \mathrm{N} \\
24^{\circ} 49^{\prime} \mathrm{E}\end{array}$ & $30^{\circ}$ \\
\hline
\end{tabular}

Since the wave modelling technique in use relies on the one-point wind from the central part of the Gulf of Finland, it may fail to correctly represent wave conditions in a few strong storms in which the wind speed in the northern Baltic proper may vary substantially from that in the Gulf. Such a situation actually occurred in January 2005 (Suursaar et al. 2006). Therefore the above estimates should be interpreted as the minimum values of the closure depth.

The basic properties of wave climate vary about $5 \%$ in different sections of the beach (Table 3). The annual mean significant wave height at Pirita varies from $0.29 \mathrm{~m}$ to $0.32 \mathrm{~m}$. The corresponding closure depth according to Houston (1966) is 1.92-2.15 m. This is clearly underestimated (Soomere et al. 2007).

Table 3. Parameters of the modelled wave climate at Pirita beach for 1981-2002.

The estimates are given for 3-hour mean values of the parameters of wave fields. The values of the maximum significant wave height given in square brackets are only valid for the deeper parts of the relevant sectors. The typical peak period in strong storms $T_{s}=7 \mathrm{~s}$ in used in Eq. (4) 


\begin{tabular}{|c|c|c|c|c|c|c|c|c|c|c|c|}
\hline \multirow{2}{*}{$\begin{array}{c}\text { Sector } \\
\text { No. / } \\
\text { mean } \\
\text { depth }\end{array}$} & \multicolumn{2}{|c|}{$\begin{array}{l}\text { Significant wave } \\
\text { height } H_{\mathrm{s}}, \mathrm{m}\end{array}$} & \multicolumn{7}{|c|}{$\begin{array}{l}\text { Significant wave height occurring with the given } \\
\text { probability in } 1981-2002\end{array}$} & \multicolumn{2}{|c|}{ Depth of closure, $m$} \\
\hline & $\begin{array}{c}\operatorname{maximum}, \\
\mathrm{m}\end{array}$ & $\begin{array}{c}\text { average, } \\
\mathrm{m}\end{array}$ & $50 \%$ & $25 \%$ & $10 \%$ & $5 \%$ & $2.5 \%$ & $1 \%$ & $0.137 \%$ & $\begin{array}{l}\text { based on } H_{s}^{a} \\
\text { Houston } 1966\end{array}$ & $\begin{array}{c}\text { Birke- } \\
\text { meier } \\
1985\end{array}$ \\
\hline $1 / 3$ & [2.645] & 8 & .255 & 0.416 & 0.625 & 0.762 & 0.875 & 1.07 & 1.54 & 0 & 2.50 \\
\hline $2 / 3$ & [2.65] & 0.313 & 0.258 & 0.418 & 0.641 & 0.770 & 0.920 & 1.10 & 1.58 & 2. & 2.57 \\
\hline $3 / 4$ & [2.45] & 0.307 & 0.254 & 0.413 & 0.628 & 0.755 & 0.894 & 1.06 & 1.51 & 2.07 & 2.45 \\
\hline $4 \mathrm{a} / 7$ & 2.32 & 0.319 & 0.268 & 0,429 & 0.643 & 0.778 & 0.921 & 1.09 & 1.56 & 2.15 & 2.54 \\
\hline $4 \mathrm{~b} / 2$ & [2.25] & 0.285 & 0.232 & 0.379 & 0.577 & 0.700 & 0.831 & 1.01 & 1.45 & 1.92 & 2.36 \\
\hline $5 / 6$ & 2.34 & 0.306 & 0.254 & 0.405 & 0.616 & 0.753 & 0.881 & 1.08 & 1.53 & 2.07 & 2.50 \\
\hline
\end{tabular}

\section{Modelled littoral drift}

\subsection{CERC model}

It is convenient to estimate the intensity of alongshore sediment transport in terms of its potential rate $Q_{t}$ (Coastal Engineering Manual 2002). This measure expresses the volume of sediments carried through a cross-section of the beach in ideal conditions within a unit of time. An equivalent measure is the potential immersed weight transport rate

$I_{t}=\left(\rho_{s}-\rho\right) g(1-p) Q_{t}$,

that accounts for voids between sediment particles and the specific weight of the sediment components. Here $\rho_{s}$ and $\rho$ are the densities of sediment particles and sea water, respectively, $g=9.81 \mathrm{~m} / \mathrm{s}^{2}$ is the acceleration due to gravity and $p$ is the porosity coefficient. The sign of the potential transport rate is usually chosen so that the motion from the left to the right hand of the person looking to the sea is positive. The sign and the value of the integral of the transport rate show the dominant direction and the magnitude of net transport, respectively. The ratio of the net and bulk (the integral of the modulus of the transport rate) potential transport characterises the intensity of transit of sediments through the section in question compared to the back-and-forth motions.

The actual transport is usually much smaller then the estimated net or bulk potential transport. The difference is particularly large when the sediment layer is not continuous (as it is northwards from Pirita) or has a limited thickness. However, the difference between the estimates for different sections of the beach carries the key information 
about their particular role in sediment recycling, and about their potential vulnerability with respect to changes of sediment transport processes. Another key quantity is the ratio of net and bulk transport rates. It characterizes to some extent how vulnerable a section is with respect to changes at a particular side.

We use the CERC (Coastal Engineering Research Council) method to estimate the potential transport rate (Coastal Engineering Manual 2002). It is based on the assumption that the potential transport intensity $Q_{t}$ is proportional to the shoreward wave energy flux (wave power). The power of a monochromatic wave field is $\vec{P}=E \vec{c}_{g}$, where $E$ is the wave energy and $\vec{c}_{g}$ is the group velocity. If waves approach the coast under an angle $\alpha$, the shoreward component of the energy flux is $P_{t}=E c_{g} \cos \alpha$ and the rate of its beaching per unit of the coastline is

$P_{t}=E c_{g} \sin \alpha \cos \alpha$, where $c_{g}=\left|\vec{c}_{g}\right|$.

Since the majority of sediment transport occurs in the surf zone, energy and group velocity are usually chosen to express the properties of the wave field at the seaward border of the surf zone. Breaking waves are reasonably well described as long waves, thus their energy and group velocity at the breaker line are

$$
E_{b}=\frac{\rho g H_{b}^{2}}{8}, c_{g b}=\sqrt{g d_{b}}=\sqrt{\frac{g H_{b}}{\kappa}},
$$

where $H_{b}$ is the wave height at breaking, $\kappa=H_{b} / d_{b}$ is the breaking index and $d_{b}$ is the breaking depth (Coastal Engineering Manual 2002). Since the quantities $P_{t}$ and $I_{t}$ have the same dimension, their relation can be expressed as

$I_{t}=K P_{t}$,

where $K$ is a nondimensional coefficient. The latter expression is usually referred to as the CERC formula. Combining the above formulae leads to the following well-known expression for the potential transport rate: 
$Q_{t}=\frac{K \rho \sqrt{g}}{16\left(\rho_{s}-\rho\right)(1-p) \sqrt{\kappa}} H_{b}^{2} \sqrt{H_{b}} \sin 2 \alpha_{b}$.

We employ the following empirical dependence of the coefficient $K$ on properties of the wave field and sediments (Coastal Engineering Manual 2002):

$K=0.05+2.6 \sin ^{2} 2 \alpha_{b}+0.007 u_{m b} / w_{f}$,

where $\alpha_{b}$ is the angle between the wave crests and the isobaths,

$u_{m b}=\frac{\kappa}{2} \sqrt{g d_{b}}$

is the maximum orbital velocity in breaking waves within the linear wave theory and

$$
w_{f}=1.6 \sqrt{g d_{50} \frac{\rho_{s}-\rho}{\rho}} .
$$

is the approximation of fall velocity in the surf zone (Coastal Engineering Manual 2002, part III-1)

\subsection{Properties of breaking waves}

The properties of the wave field (significant wave height, peak period, and propagation direction) were calculated for each 3-hour time slice at the centroids of the sectors (Fig. 8) located beyond the surf zone for typical wave conditions. These properties and the potential sediment transport were assumed to be constant within such time slices. The modifications of the wave properties owing to wave propagation up to the surf zone were estimated based upon linear wave theory and the assumption that the wave energy is concentrated in monochromatic plane waves with the period equal to the peak period and the direction of propagation equal to the mean propagation direction.

Given the uncertainties in wind data and wave hindcast, more exact calculation of transport properties based on the full wave spectrum is not reasonable. For the same reason, the estimate of shoaling of waves propagating from the centroids to the surf zone was not calculated but was approximated indirectly, by choosing the breaking index $\kappa=1$. In this approximation, $d_{b}=H_{b}$ and the breaking wave height is simply equal to the modelled wave height at the centre of each sector. 
The change of the propagation direction of waves follows the Snell's law

$$
\frac{\sin \theta}{c_{f}}=\text { const }
$$

where $\theta$ is the angle between the wave crests and the isobath and

$$
c_{f}=\frac{\omega}{k}=\frac{\sqrt{g k \tanh (k h)}}{k}=\sqrt{\frac{g \tanh (2 \pi h / L)}{2 \pi / L}} .
$$

is the wave celerity (phase velocity). Wave number $k=2 \pi / L$ ( $L$ is the wave length) and period satisfy the dispersion relation

$$
\omega=\frac{2 \pi}{T}=\sqrt{g k \tanh (k h)}
$$

For a given water depth $h$ and peak period T, Eq. (15) is a transcendental equation for the wave number. Its approximate solution, allowing determination of the wave vector with an error not exceeding $1.7 \%$, is (Dean and Dalrymple 2002, p. 90)

$$
L=L_{0}\left\{\tanh \left[\left(2 \pi \sqrt{\frac{h}{g T^{2}}}\right)^{3 / 2}\right]\right\}^{2 / 3},
$$

where $L_{0}=g T^{2} /(2 \pi)$ is the length of waves with period $T$ in deep water.

The computations were performed as follows. From the modelled wave data, phase velocity of waves at the centroids and at the breaker line was found with the use of Eqs. (14) - (17). The angle $\alpha_{b}$ at the breaker line was determined from the Snell's law (13). The values of $\alpha_{b}$ and breaking depth $d_{b}$ were used together with the mean grain size $d_{50}$ and the difference $\rho_{s}-\rho$ to determine the CERC coefficient $K$ from Eqs. (10)-(12). The potential transport rate for the given wave conditions within each 3-hour time interval was calculated from Eq. (9). Finally, annual values of the net and bulk potential transport rates (Table 4) were calculated. 


\subsection{Sediment transport in different sections of the beach}

Numerically modelled potential rate $Q_{t}$ of annual sediment transport based on wave conditions in 1982-2001 are presented in Table 4 for three values of the mean grain size. The results suggest that the transport rate (consequently, also the overall functioning of the sedimentary system at Pirita) is virtually independent of the particular grain size. A noteworthy difference can be found only for the net transport rate for sand of $d_{50}=0.1 \mathrm{~mm}$. The overall decrease of the transport rates with the decrease of the grain size is fairly modest.

Physically, this means that the third term in Eq. (10) is almost negligible. Notice that this term represents the combination of wave properties responsible for the nearbottom orbital velocity and sediment properties. Sand transport at Pirita is thus almost entirely governed by the match of the wave propagation direction with the geometry of the coast. Therefore potential changes of the transport patterns when the grain size is modified e.g. through beach refill are fairly modest. Only the probability of northward transport of sand with a mean grain size $\sim 0.1 \mathrm{~mm}$ may be larger than for other grain sizes.

Table 4. Potential transport rate along Pirita Beach for the various sectors (Fig. 8).

The rates are presented for the following fractions: $d_{50}=0.063 \mathrm{~mm}$ (fall velocity $5.1 \mathrm{~cm} / \mathrm{s}$ ), $d_{50}=0.1 \mathrm{~mm}$ (fall velocity $6.4 \mathrm{~cm} / \mathrm{s}$ ) and $d_{50}=0.2 \mathrm{~mm}$ (fall velocity 9.1 $\mathrm{cm} / \mathrm{s})$.

\begin{tabular}{|c|c|c|c|c|c|c|c|c|c|}
\hline \multirow{2}{*}{$\begin{array}{l}\text { Sector } \\
\text { No. }\end{array}$} & \multicolumn{2}{|c|}{$d_{50}=0.063 \mathrm{~mm}$} & \multicolumn{3}{c|}{$d_{50}=0.1 \mathrm{~mm}$} & \multicolumn{3}{c|}{$d_{50}=0.2 \mathrm{~mm}$} \\
\cline { 2 - 11 } & $\begin{array}{c}\text { Potential } \\
\text { transport rate } \\
1000 \mathrm{~m}^{3} / \text { year }\end{array}$ & \multicolumn{3}{|c|}{$\begin{array}{c}\text { Potential transport } \\
\text { rate } 1000 \mathrm{~m}^{3} / \text { year }\end{array}$} & \multicolumn{3}{c|}{$\begin{array}{c}\text { Potential } \\
\text { transport rate } \\
1000 \mathrm{~m}^{3} / \text { year }\end{array}$} & \\
\cline { 2 - 12 } & Bulk & Net & $\%$ & Bulk & Net & $\%$ & Bulk & Net & $\%$ \\
\hline 1 & 626 & -574 & $\mathbf{- 9 2}$ & 610 & -409 & $\mathbf{- 8 0}$ & 592 & -543 & $\mathbf{- 9 2}$ \\
\hline 2 & 419 & -63 & $\mathbf{- 1 5}$ & 409 & -62 & $\mathbf{- 1 6}$ & 397 & -60 & $\mathbf{- 1 5}$ \\
\hline 3 & 332 & 34 & $\mathbf{1 0}$ & 323 & 33 & $\mathbf{1 0}$ & 314 & 33 & $\mathbf{1 1}$ \\
\hline $4 \mathrm{a}$ & 287 & 31 & $\mathbf{1 1}$ & 278 & 30 & $\mathbf{1 1}$ & 269 & 29 & $\mathbf{1 1}$ \\
\hline $4 \mathrm{~b}$ & 374 & 48 & $\mathbf{1 3}$ & 365 & 47 & $\mathbf{1 3}$ & 356 & 45 & $\mathbf{1 3}$ \\
\hline 5 & 258 & 20 & $\mathbf{8}$ & 250 & 20 & $\mathbf{8}$ & 243 & 19 & $\mathbf{8}$ \\
\hline
\end{tabular}

The bulk potential transport rate in the northernmost sectors evidently exceeds the factual transport by about two orders of magnitudes. The transport may have been more 
intense under natural conditions, before Miiduranna Port and Merivälja Jetty were constructed, but even then its factual intensity was much smaller than the estimated value because of limited amount of finer sediments in the system. One could estimate the factual magnitude of the littoral drift based on the accumulation rate in the vicinity of Miiduranna Port and the dredging requirement of its fairways - data which is currently not available.

The estimates of transport in sector 5 do not necessarily match reality because of the blocking and sheltering effect of the moles of Pirita Harbour. The bulk rates of potential transport in the middle sections 3 and 4 of Pirita Beach are reasonable and give a flavour of the intensity of coastal processes in the area whereas the net rates seem to be overestimated.

The ratio of bulk and net potential transport rates reveals a basic pattern of sediment transport (Soomere et al. 2007). The transport in the northernmost sector 1 is almost (>90 \%) unidirectionally southwards. This sector therefore hosts intense sediment transit and any decrease of the sediment supply generally leads to an acute sediment deficit and potential beach erosion. This is exactly what is observed in the area where the sandy strip ends. The till cliff is intensively eroded; in places at a rate of up to $1 \mathrm{~m} /$ year.

Southwards transport also prevails in sector 2 . The reaction of the beach to a decrease of sediment supply from the North apparently is milder. This sector possesses a revetment built in the 1980s along the dune toe. During the two decades, waves have eroded the protected part of the dune so that a part of the revetment is located in the middle of the sandy strip today (Soomere et al. 2007).

There is no clearly identifiable direction of sediment transport in the middle and southern sectors (3-5) of the beach. Somewhat surprisingly, numerically modelled net transport has a slight prevalence of a northward flux whereas observations suggest a slight domination of southward sediment flux. The inconsistency, however, is insignificant and may reflect specific conditions within different study periods. It may also stem from the uncertainties of modelled wave fields caused by the use of singlepoint wind field from a remote measurement site and by an insufficient resolution of propagation direction of waves approaching to Pirita. As explained above, much of these 
uncertainties are connected with generic vagueness of existing wind data. Another potential source of error is the spatial resolution of the innermost wave model (1/4 miles). Although the grid is uncommonly fine for open sea wave studies, it may still be not sufficient for proper resolving effects of wave refraction on small-scale bathymetric features of Tallinn Bay.

Generally the small ratio of the net and bulk potential transport rates indicates that no dominating transport direction exists in the area. This feature combined with the overwhelming dominance of southwards transport in the northern sectors implies that sand accumulation should take place in the middle and southern sectors of the beach. While certain accumulation indeed occurs in the southernmost sector, the middle sectors of the beach (3 and 4) show no obvious accumulation features. The position of the coastline is almost unchanged since 1980 although the land uplift together with accumulation should have led to widening of the dry beach. On the contrary, a certain amount of dry sand apparently has been eroded from this section between 1997 and 2006 (Soomere et al. 2007).

The above discussion together with the apparent sand loss from the area (Soomere et al. 2007) suggests that an interesting (albeit somewhat speculative) pattern of sand motion may take place at Pirita. If the slight dominance of the northward-directed transport actually takes place, sand loss to offshore mostly occurs from the middle section of the beach. This feature may be one of the reasons why beach renourishment by placing sand in the middle of the beach had a limited positive influence (Soomere et al. 2007). This hypothetical pattern may also support the existence of the wide and low sand bar at medium depths (Fig. 2) that seems to stem from the middle section of the dry beach.

\section{Conclusions and Discussion}

Pirita Beach is an example of a bayhead beach, the natural evolution of which occurs predominantly under wave action in tideless conditions. Its sand volume consists primarily of fine sand with an average grain size of about $0.12 \mathrm{~mm}$. The distribution of

the dominant grain size is more or less homogeneous along the entire beach and the nearshore except that coarser sand is concentrated along the waterline. 
The beach apparently developed in a stable manner until the 1970s. Later on, largescale coastal engineering constructions at its both sides such as Pirita Harbour or Miiduranna Port cut down the supply of coarser sediments. The beach seems to suffer from sediment deficit and its active sand volume is apparently decreasing.

Wave climate at Pirita is normally very mild, but high energy waves accompanying storm surges episodically attack the beach. The long-term average significant wave height is as low as about $30 \mathrm{~cm}$ but strong wave storms in which the significant wave height exceeds $2 \mathrm{~m}$ appear once in 2 years. The depth of closure ranges from 2.4 to $2.6 \mathrm{~m}$ for different sections of the beach. The width of the equilibrium profile is about $250 \mathrm{~m}$ and its mean slope is from 1:100 to 1:150. Southward sediment transport dominates in the northern part of the beach whereas no unambiguous direction of littoral drift can be identified for its middle and southern sectors.

The beach is fed by the flux of relatively fine sediments along the western coast of the Viimsi Peninsula (say, with a magnitude $P$ ) and by unsorted material abraded from the cliff between the beach and Merivälja Jetty. The cliff contains roughly 1/3 of sand and gravel. If the amount of $M$ is abraded from the cliff, the beach receives about $\frac{1}{3} M$ of material. Also, at times a certain amount of sand $S$ is eroded from the dune scarp and berm along the sandy beach. The latter two quantities can be quite accurately estimated from the results of subsequent topographic surveys; for example, $S \approx 400 \mathrm{~m}^{3} /$ year in 1997-2006 (Soomere et al. 2007).

The earlier observations suggest that the sand volume of the beach was more or less unchanged before the 1970s. The balance equation for the sand volume was thus:

$$
\Delta Q=P+\frac{1}{3} M+S-D=0
$$

where $D$ is the net loss of sand volume to the deeper areas. There are no lateral loss terms in Eq. (17), because (i) Pirita Harbour completely stops the littoral drift and (ii) the southwards drift overwhelmingly dominates at the northern border of the beach. The resulting equation provides a key for a rough estimate for the magnitude of the littoral drift from the North in the past. It can be found provided the average rate $D$ of net sand loss from the beach to offshore is known. This rate can probably be found with the use of 
the subsequent surveys of the underwater slope and accounting for the local land uplift. The relevant study is in progress.

The established features of the wave climate, properties of the equilibrium profile and sediment transport patterns play an important role in planning of beach nourishment activities. A feasible way of restoring the sand balance at Pirita and making the beach stable consists of increasing the sand volume at the beach. The fastest results would utilize classical beach nourishment - placing of sand either in the dry land area or into the immediate vicinity of the coastline. Dumping of sand at large depths is ineffective owing to the relatively small closure depth (Verhagen 1992). Filling the beach with sand from the Pirita river mouth or from the Olympic Harbour basin should be undertaken with great care, because sand there is relatively fine, contain silts, and may be partially contaminated. Another feasible way would be to bypass sand around Miiduranna Port and to place it in the surf zone on its southern side. Doing so would eventually compensate the sediment deficit along the coast at Merivälja (and thus reduce the coastal erosion in this area) and would supply medium and coarse sand to Pirita.

An obvious conclusion from the existence of the single maximum of the average grain size in the cross-shore direction is that material with much smaller grain size than the natural sand at the waterline, will be lost relatively fast. An important principle of beach management is that relatively coarse and well-sorted sand is believed to create the best recreational value. Beach refill with fine sand will lead to a decrease of the amenity value of this beach.

A further deduction can be inferred from the above hypothetical sediment transport pattern in which the offshore sand loss occurs from the middle sections of the beach. The obvious area for placing the renourishment material is the northern section of the beach, from which the material would gradually be distributed downdrift along the beach. A side effect of placing sand in the northernmost sectors of the beach is that the till cliff would be more protected against high waves. Consequently, beach renourishment may lead to a seeming increase of net sand loss $\Delta Q$ through reduction of the quantity $M$ in Eq. (17).

Indeed, any construction activities in the vicinity of the beach or its sand supply channels, even if designed as beach protection measures, may substantially increase the 
net sand loss $\Delta Q$. For example, if the till cliff north from the beach was to be protected by a seawall or a revetment, much less abraded till material would be supplied to the beach. The revetment enhances the sediment deficit in the northernmost section of the sandy beach where the intensity of dune scarp erosion would increase. Major development works at Merivälja jetty or dredging the fairway to this jetty would lead to similar consequences.

\section{Acknowledgements}

This study was supported by the Estonian Science Foundation (Grant 7413) and was partially performed within the Marie Curie Research and Training network SEAMOCS (MRTN-CT-2005-019374). A large part of the work was done when TS was visiting the Centre of Mathematics for Applications, University of Oslo in the framework of the Marie Curie Transfer of Knowledge project CENS-CMA (MC-TK-013909). Visits of TH to Tallinn as well as a part of the analysis of sediment samples were supported by the structural funds of the EU in the framework of the INNOVE project 1.0101-0208.

\section{References}

Alenius, P., Myrberg, K., Nekrasov, A., 1998. The physical oceanography of the Gulf of Finland: A review. Boreal Env. Res. 3 (2), 97-125.

Alexandersson, H., Schmith, T., Iden K., Tuomenvirta H., 1998. Long-term variations of the storm climate over NW Europe. The Global Atmosphere and Ocean System 6, 97-120.

Birkemeier, W.A., 1985. Field data on seaward limit of profile change. Journal of Waterway, Port, Coastal and Ocean Engineering - ASCE 111 (3), 598-602.

Broman, B., Hammarklint, T., Rannat, K., Soomere, T., Valdmann, A., 2006. Trends and extremes of wave fields in the north-eastern part of the Baltic Proper. Oceanologia 48 (S), 165184.

Climatological Ice Atlas for the Baltic Sea, Kattegat, Skagerrak and Lake Vänern (1963-1979), 1982, SMHI, Swedish Meteorological and Hydrological Institute, Norrköping, Sweden, and Institute of Marine Research, Helsinki, Finland, Norrköping, 220 pp.

Coastal Engineering Manual, 2002. Department of the Army. U.S. Army Corps of Engineers. Manual No. 1110-2-1100.

Dean, R.G., 1991. Equilibrium beach profiles: characteristics and applications. J. Coastal Res. 7 (1), 53-84.

Dean, R.G., Walton, T.L, Kriebel, D.L., 2001. Cross-shore sediment transport, in Coastal Engineering Manual, U.S. Army Coastal and Hydrodynamics Laboratory, 2001 (CD).

Dean, R.G, Dalrymple, R.A., 2002. Coastal processes with engineering applications. Cambridge University Press, 475 pp.

Davies, A.G., Villaret, C., 2002. Prediction of sand transport rates by waves and currents in the coastal zone. Cont. Shelf Res., 22 (18-19), 2725-2737.

Erm, A., Soomere, T., 2006. The impact of fast ferry traffic on underwater optics and sediment resuspension. Oceanologia, 48 (S), 283-301. 
Friedman, G.M., Sanders, J.E., Kopaska-Merkel, D.C., 1992. Principles of Sedimentary Deposits, Macmillan Publ. Co., New York, p. 335-340.

Houston J.R., 1996. Simplified Dean's method for beach-fill design. Journal of the Waterway and Harbours divison. ASCE 122, 143-146.

Jönsson, A., 2005. Model studies of surface waves and sediment resuspension in the Baltic Sea. $\mathrm{PhD}$ Thesis, Linköping Studies in Arts and Science No. 332, Linköping University, Linköping 2005.

Kahma, K., Pettersson, H., 1994. Wave growth in a narrow fetch geometry. The Global Atmosphere and Ocean System 2, 253-263.

Kask, J., Talpas, A, Kask, A., Schwarzer, K., 2003. Geological setting of areas endangered by waves generated by fast ferries in Tallinn Bay. Proc. Estonian Acad. Sci. Eng. 9, 185-208.

Kask, J., Soomere, T., Kask, A., Kotta, J., Kotta, I., Martin, G., Eschbaum, R., Vetemaa, M., Verliin, A., Kesler, M., Saat, T. 2005. Post-mining environmental monitoring of the area of sand mining near the south-western coast of Naissaar. Year 1. Manuscript. Marine Systems Institute at Tallinn Technical University. Tallinn [in Estonian]

Komen, G.J., Cavaleri, L., Donelan, M., Hasselmann, K., Hasselmann, S., Janssen, P.A.E.M., 1994. Dynamics and modelling of ocean waves. Cambridge University Press, 532 pp.

Kuhrts, C., Fennel, W., Seifert, T., 2004. Model studies of transport of sedimentary material in the western Baltic. J. Marine Syst. 52 (1-4), 167-190.

Laanearu, J., Koppel, T., Soomere, T., Davies, P.A., 2007. Joint influence of river stream, water level and wind waves on the height of sand bar in a river mouth. Nordic Hydrology 38, 287-302, doi: 10.2166/nh.2007.012.

Lopatukhin L.I., Bukhanovsky A.V., Ivanov S.V., Tshernyshova E.S. 2006. Handbook of wind and wave regimes in the Baltic Sea, North Sea, Black Sea, Azov Sea and the Mediterranean. Russian Shipping Registry, Sankt-Petersburg 2006, 450 pp. (In Russian).

Lutt, J., 1985. Bottom sediments of Väinameri sea area. Valgus, Tallinn, 210 pp. [in Russian].

Lutt, J., 1992. Bottom deposits. In: Raukas, A., Hyvärinen, H. (Eds.), Geology of the Gulf of Finland. Valgus, Tallinn, pp. 158-218 [in Russian].

Lutt, J., Tammik, P., 1992. Bottom sediments of Tallinn Bay. Proc. Estonian Acad. Sci. Geol. 41, 81-86 [in Estonian].

Lutt J., Kask J., 1992. Sources of sedimention. In: Raukas, A., Hyvärinen, H. (Eds.), Geology of the Gulf of Finland. Valgus, Tallinn, pp. 137-157 [in Russian].

Mietus, M. (co-ordinator), 1998. The climate of the Baltic Sea basin, Marine meteorology and related oceanographic activities, Report No. 41, World Meteorological Organization, Geneva, 64 pp.

Miidel, A., Jantunen, T., 1992. Neotectonics and contemporary movements. In: Raukas, A., Hyvärinen, H. (Eds.), Geology of the Gulf of Finland. Valgus, Tallinn, pp. 87-98 [in Russian].

Nicholls, R.J., Birkemeier W.A., Hallermeier R.J., 1996. Application of the depth of closure concept, In: Proc. 25th Int. Conf. Coastal Eng., ASCE, Orlando, 3874-3887.

Orlenko, L.R., Lopatukhin L.I., Portnov G.L. (Eds.), 1984. Studies of hydrometeorological regime of Tallinn Bay. Leningrad, Gidrometeoizdat, 152 pp. (in Russian).

Orviku, K., 1974. Estonian coasts. Tallinn, 112 pp. [in Russian]. 
Orviku, K., Granö, O., 1992. Contemporary coasts. In: Raukas, A., Hyvärinen, H. (Eds.), Geology of the Gulf of Finland. Valgus, Tallinn, pp. 219-238 [in Russian].

Orviku K., Jaagus J., Kont A., Ratas U., Rivis R., 2003. Increasing activity of coastal processes associated with climate change in Estonia. J. Coastal Res. 19, 364-375.

Pettersson, H., 2001, Directional wave statistics from the Gulf of Finland. MERI, 44, Finnish Institute of Marine Research, 37 pp.

Pettersson, H., Boman, H., 2002. High waves and sea level during the November storm. In: Annual report 2001, Finnish Institute of Marine Research, Helsinki, 7

Raukas, A., Teedumäe A., 1997. Geology and mineral resources of Estonia. Estonian Academy Publishers, Tallinn, $436 \mathrm{pp}$.

Soomere, T., 2001. Wave regimes and anomalies off north-western Saaremaa Island. Proc. Estonian Acad. Sci. Eng. 7 (2), 157-173.

Soomere, T., 2005. Wind wave statistics in Tallinn Bay. Boreal Env. Res. 10 (2), 103-118.

Soomere, T., Kask, A., Kask, J., Nerman, R., 2007. Transport and distribution of bottom sediments at Pirita Beach. Estonian J. Earth. Sci. 56 (4), 233-254.

Soomere, T., Kask, A., Kask, J. 2005. Environmental studies of coastal zone of Pirita Beach and formulation of technical conditions of beach protection. Research report. Institute of Cybernetics at Tallinn University of Technology, Tallinn, $139 \mathrm{pp}$. [in Estonian]

Soomere, T., Keevallik, S., 2003. Directional and extreme wind properties in the Gulf of Finland, Proc. Estonian Acad. Sci. Eng. 9 (2), 73-90.

Soomere, T., Rannat, K., 2003. An experimental study of wind waves and ship wakes in Tallinn Bay. Proc. Estonian Acad. Sci. Eng. 9 (3), 157-184.

Soomere T, Zaitseva, I., 2007. Estimates of wave climate in the northern Baltic Proper derived from visual wave observations at Vilsandi. Proc. Estonian Acad. Sci. Eng. 13 (1), 48-64.

Suursaar, Ü., Kullas, K., Otsmann, M., Saaremäe, I., Kuik, J., Merilain M., 2006. Hurricane Gudrun and modelling its hydrodynamic consequences in the Estonian coastal waters, Boreal Env. Res. 11, 143-159.

Tuomi, L., Pettersson, H., Kahma, K., 1999. Preliminary results from the WAM wave model forced by the mesoscale EUR-HIRLAM atmospheric model. MERI - Report series of the Finnish Institute of Marine Research 40, 19-23.

Vallner, L., Sildvee, H., Torim, A. 1988. Recent crustal movements in Estonia. - Journal of Geodynamics, 9, 215-223.

Verhagen, H.J., 1992. Method for artificial beach nourishment. In: Proc. 23th International Conference on Coastal Engineering, Venice, Italy, 2474-2485.

Zhelnin G., 1966. On the recent movements of the Earth's surface in the Estonian S.S.R. Annales Academiae Scientiarum Fennicae A III. Geologica-Geographica. Helsinki, 90, 489-493. 